\title{
議論の意味構造の可視化*
}

角 康之**

\section{Visualizing the Semantic Structure of Discussion}

\author{
Yasuyuki SumI
}

\section{1.はじめに}

筆者らは，人間同士のコミュニケーションを支援する 技術に関する研究を進めており，そのひとつとして，グ ループ内で行なわれる議論の活性化や議論全体の構造の 認識・分析の支援を目的とするコンピュータシステムの 開発を行なっている. 本稿では, 議論内容の意味的な構 造の可視化について述べる.

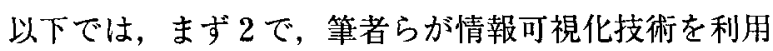
してグループ内の議論のどのような側面を支援しようと 考えているのかを明らかにする．次に 3 で，筆者らが開 発したコミュニケーション支援システムCSSを紹介し， 統計手法を利用した議論の意味構造の可視化について述 べる. そこでは, 可視化された議論空間の利用効果を考

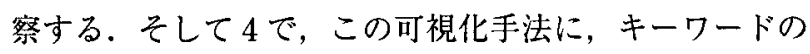
自動抽出や情報検索のための技術を統合して開発された， 議論支援システム AIDEを紹介する.

\section{2. 議論の意味構造の可視化}

筆者らは，議論を通して参加者が新たな発想を得たり， グループ内で情報共有が促進される効果をねらって，グ ループ内の議論を活性化させることを目的とするシステ ムを開発している，そのための手段として，議論内容の 意味的構造を可視化し参加者に提供する手法をとってき た. そうすることで, 参加者は話題空間の全体構造の認 識や，その中での特定の参加者や話題の位置づけの分析 を行なうことが容易になると期待されるからである.

グループ内での議論で出た複数の発言や話題の集合を 構造化することを考えるとき，そこで目指すべきター ゲットには以下の 2 つがあると考える.

1. 話題と発言者の関係, 発言問の因果関係, 話題の 時間的流れなどの記録と整理を行なう。

2. 時間的流れや発言者にとらわれずに，話題間の関 連性を認識・分析するための手がかりを提供する。

1.は，議論の比較的表層にある情報を処理する能力で

* 原稿受付 1998 年 10 月 1 日

** (侏)ATR 知能映像通信研究所
ある. 従来の CSCW (Computer-Supported Cooperative Work）の研究の中で, 参加者の発言を構造化する ことを目的とする研究の多くは，こちらをターゲットに している，例えば文献 1)，2）では，システムは規定さ れた議論モデルに沿ってユーザの発言を管理・構造化す る.しかしそのためには，ユーザは発言をする度に議論 全体におけるその発言の意味づけ等を意識して入力する 必要がある。

それに対し 2.は, 議論に扔ける話題の内容に踏み込 んだ構造化をする能力を要する. 上記の 1 .の能力が比 較的静的な外部記憶の生成を目的としているのに対し,2. の能力は動的な外部記憶の生成を目的としているとも言 える、筆者らは2.をターゲットとする，その際，情報 可視化技術を, 単に議論を可視化するためたけけに利用す るのではなく, 可視化情報を操作することで効果的に情 報空間（議論空間やデータベース）にアクセスするため の手段として活用することを意㘠する゙3.

\section{3. テキストオブジェクトを空間配置することによ る議論の可視化}

筆者らのグループは, データ集合を統計処理しコン ピュータデイスプレイ上の 2 次元空間に自動配置する手 法を利用して，アイデア整理やフリーディスカッション にお汁る概念構造の可視化を行なうシステムを構築して きた（例えば文献 4)，5），6）を参照されたい)。ここで はその一つであるコミュニケーション支援システム $\mathrm{CSS}^{7}$ を用いて，テキストデータの空間配置に基づいた 議論の可視化手法とその試用例を紹介する.

システムCSSの詳細な説明は文献 7）に譲りここ では簡単に紹介するにとどめる，CSSは，ユーザの思 考空間を可視化することで, ユーザの思考活動に扔ける 発想を支援することを目指したシステムである。ユーザ は「テキストオブジェクト」と呼ばれる電子化されたメ モと，それに付随したキーワードを入力する. CSSは， これらテキストオブジェクトとキーワードの集合の互い の関連性を反映した 2 次元距離空間を自動構成する。そ うすることで, ユーザの思考空間をコンピュー夕上で操 作可能にすることが权らいである.

$\operatorname{CSS}$ は, 空間の自動構成に, 双対尺度法神と呼ばれる 


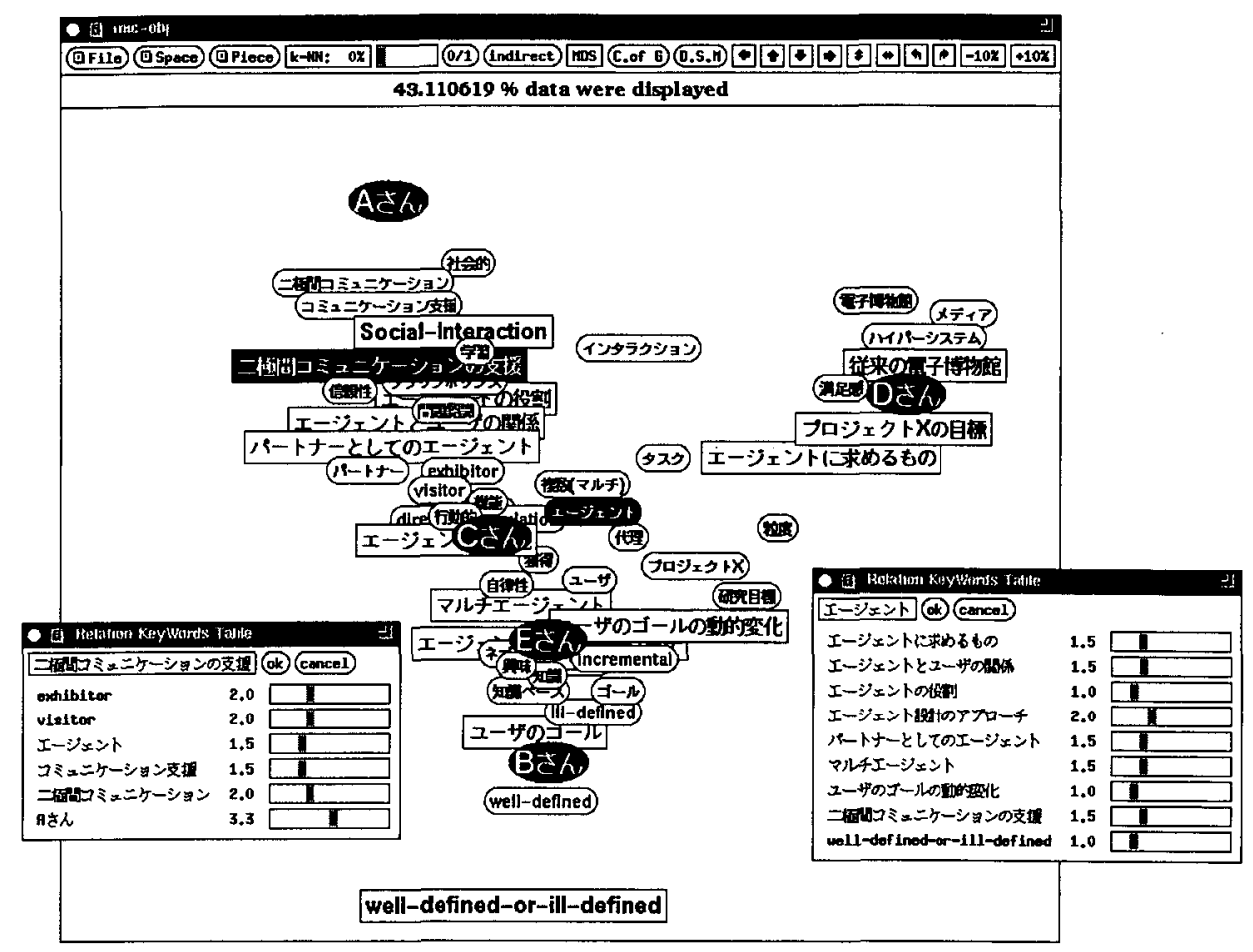

Fig. 1 Example of Using CSS for Visualizing the Result of a Discussion

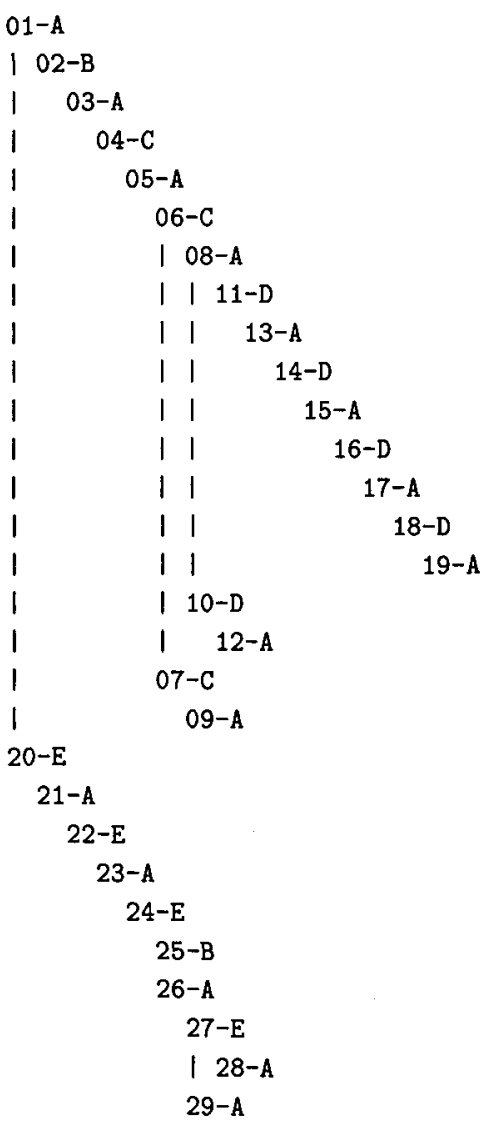

Fig. 2 Thread Representation of Disicussion

1参加者名を表すキーワードに刘応するアイコンが他のキーワード のアイコンと形状や大きさが異なるのは，ユーザが見易くするた めに操作したものであり，このようなことが容易にできるのも $\operatorname{CSS}$ の機能の一つである.
統計的手法を採用している，双対尺度法とは，複数の数 量化属性で構成されたオブジェクト集合を与えられたと きに，オブジェクト同士の属性共有性と属性同士の共起 性を顕在化するように空間構造を可視化する手法である. ここでは，コーザによって宣言されたキーワードを属性 と考え, それらの重要度を属性值とすることで, 双対尺 度法を適用した。このことにより，テキストオブジェク トとそれらの構成要素としてのキーワードの関連性を, 同一の距離空間上に可視化することが可能となる.

ここで，CSSを利用して議論空間の可視化を試みた 例を 2 件紹介する ${ }^{9}$.

最初の例は, 同じ研究グループに所属する 5 人が対面 で行なったフリーディスカッションで書き残されたメモ をもとに，議論参加者の一人である筆者が CSS を利用 して議論空間を構築したものである.その結果を Fig. 1 に示す. 図中の長方形のアイコンが議論で出た話題に対 応するテキストオブジェクト, 長円形のアイコンがキー ワードである．また，大きめの楕円形のアイコンは参加 者の名前を表す。この例では, 参加者名もキーワードの 一つとして定義し，その参加者が特に積極的に関与して いた話題に対応するテキストオブジェクトにキーワード として宣言した1. そうすることで, 参加者と話題およ びそれらに関連するキーワードの関係を可視化すること ができる。

CSS が可視化した議論空間を他の 4 人の参加者に見 せたところ，まず空間中に話題に対応するクラスタを見 つけ，次にそれらの間の隙間に注目するという傾向があ ることが観察された．クラスタとクラス夕の隙間に注目 したことにともなってなされた発言の内容は参加者に 
よって異なるが，その隙間の中に新たなテーマの存在の 可能性を見つけたり，さらなる議論の必要性を感じたり する傾向が強かった．また，話題の展開やそれらの関連 性を認識するのに役立つことが確認され，それにとも なって, 議論の中心になっていた話題が再認識されたり， グループ内でのさらなる議論のきっかけが得られた，他 にも，「空間の外側にあるクラス夕は，我々の研究興味 に対する反面教師なのではないか」、「ディスカッション の全体構造を説明するような軸が空間の中に見えた」, 「本来の題目とは別の話題に議論の時間を費やしていた ことに気づかされた」,「参加者ごとの興味やグループの 中での役割分担が見える」，といった感想を得た。

次に, 別の研究グループ内で運用されているオンライ ンニュースシステム上でなされたディスカッションの記 録を実験材料として，議論空間の可視化を試みた例を紹 介する. データとして用いたのは, “design tool for design”という議題で 5 人の参加者が 23 日を費やして行 なった議論による 29 の記事集合である。この例では, 記事を“(数字) - (アルファベット)”という形式で表す こととする. 数字は発言の時間的順序を表し，アルファ ベットは発言者を表す。

比較のために, Fig. 2 に通常のニュースブラウザが提 供している記事のスレッド表現を示す。このスレッド表 現は, ニュースブラウザが記事のIn-reply-to フィールド を参照して自動生成するものであり，例えば,02-Bは 01-Aに followup したことを示している. また，Fig. 2 では, 同じ記事に対して followup している複数の記事 を縰線で結んである．例えば, 08-A と 10-D は同一の 記事 06-Cにfollowup していることを表している.

Fig. 3 は，CSS を利用して可視化した議論空間の時間 的変化を示す 3 枚のスナップショットである.これらは, CSSが出力した結果に，筆者が空間構造の解釈を書き 込んだものである。

Fig.3を見ると，CSSによって構造化された議論空間 は. 比較的期待通りに議論の移り变わりを再現している と考えられる. 例えば，Fig. 3-(1)〜(3)を順に見ていく ことによって, 徐々に話題の中心が移り変わっている様 子がわかる。つまり，(1)話題提議からまず「アナログ」 と「デジタル」の話題が始まり，(2)「設計」と「発想」 に関する広い範囲の議諭と続いて，(3)最後に話題空間の 中心からはずれていくような形で「暗黙知」の話題に発 散していく様子が見てとれる.

スレッド表現は，記事に明示的に書かれた In-reply-to フィールドを参照することによって，記事の因果関倸の 可視化を目指したものである．しかし，Fig. 2 を見ると わかるように，スレッドが単調に深くなる部分について は発言の順序は保たれるが，一つの記事に対して複数の 記事が followup している場合はその限りではない。ま た，記事を書き込む際に，followupの対象として一つ の記事だけを選ばなければならないということは, 新し
い発言を書き込むユーザにとって強い負担になることが ある。例えば，ここで使用した記事集合において,20Eはそれまでの議論全体に対する followup を行なった ものと思われるが, 現在のニュースシステム上では複数 の記事を followup の対象として指定することが無理で あるため，苦肉の策として，まったく新たなスレッドを 生成している。つまり，どの記事に対しても followup していない。しかし，明らかに内容はそれまでの多くの 議論をふまえた発言であることは，Fig.3ー(3)を見れば 明らかである．発言の位置づけを意識してもらうことが ユーザの大きな負担になってしまうことは, 従来の, 規 定された議論モデルに基づいた議論管理システム皇,2)に 共通した欠点である。

CSSによる可視化情報の特長は，発言間の意味的関 連性が位相情報として表現されるだけでなく，話題を構 成しているキーワードも含めて空間構造を構成している ことである.このことによって，ディスカッションへの 参加者は, 議論空間全体に扔ける自分の発言の位置づけ や，自分の使った言葉と他の参加者の言葉の関連性を認 識することができる，また，議論に参加していなかった 第三者にとっても，議論空間が成長する様子を認識する ことができ，空間上に配置されるキーワードを見ること で議論内容や文脈の見当をつけることができる.

\section{4.議論支援システム AIDE}

$\operatorname{CSS}$ の開発から, 空間配置を利用した議論の可視化 手法の有效性を確かめた結果を受け，筆者らは新たに統 合的な議論支援システムAIDEを開発した101.111. AIDE はネットワークを介した議論を行なうための, クライア ントサーバ型の（テキストベースの）電子会議システム である．利用形態は主に分散・非同期を想定して開発し たが，対面／分散，同期／非同期のどのような組み合わ せでも利用可能である (Fig. 4 に対面・同期の利用概観 を示す).

Fig. 5 に AIDE 使用時の画面例を示す．図中の左にあ るメインウィンドウ(発言入力部と発言の履歴を有する) を見た限りでは単純な議論履歴記録システムであるが, 以下に示すような 3 つのサブシステムが加えられている ことがAIDEの特徴である（Fig. 5 と Fig. 6 を参照され たい).

\section{Discussion Viewer}

議論の意味構造を可視化した議論空間（Fig.6の Discussion space）を表示する. 議論参加者全員の共有 情報空間として利用される。

\section{Conversationalist}

議論空間に関連するテキストを外部テキストベースか ら自動抽出し, 自律的な発言として議論空間にそのテ キストを投げ込む仮想的な議論参加者.

\section{Personal Desktop}

個人思考モードを支援する作業環境. 議論空間をこの 


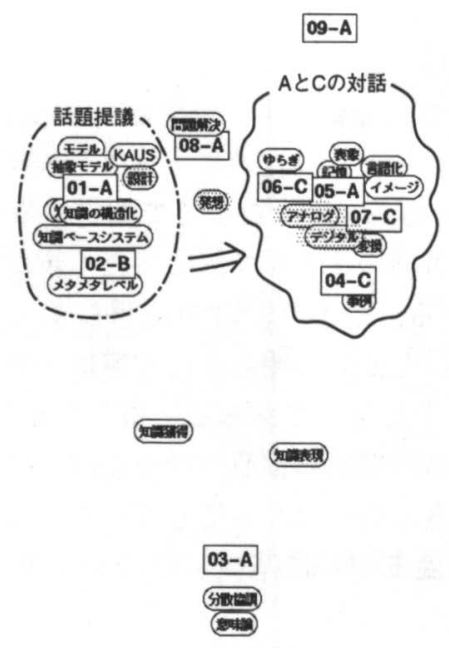

(1) Early stage of the discussion

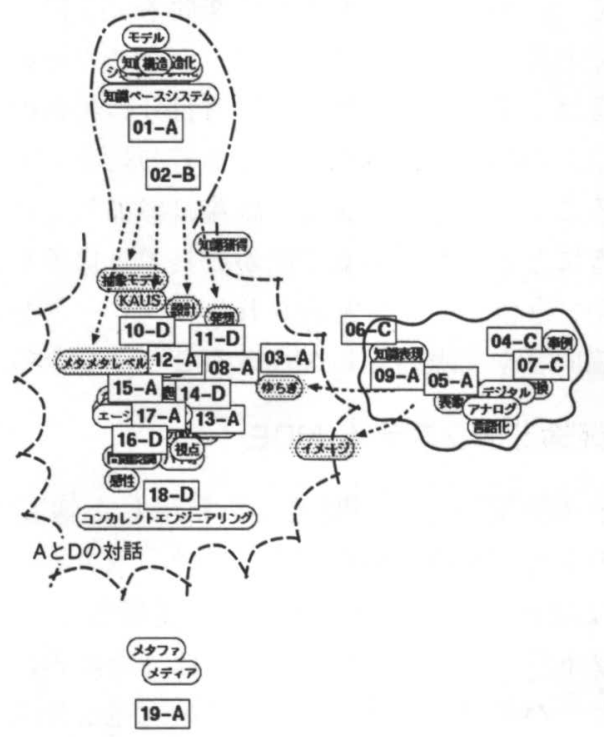

(2) Growing of the discussion space

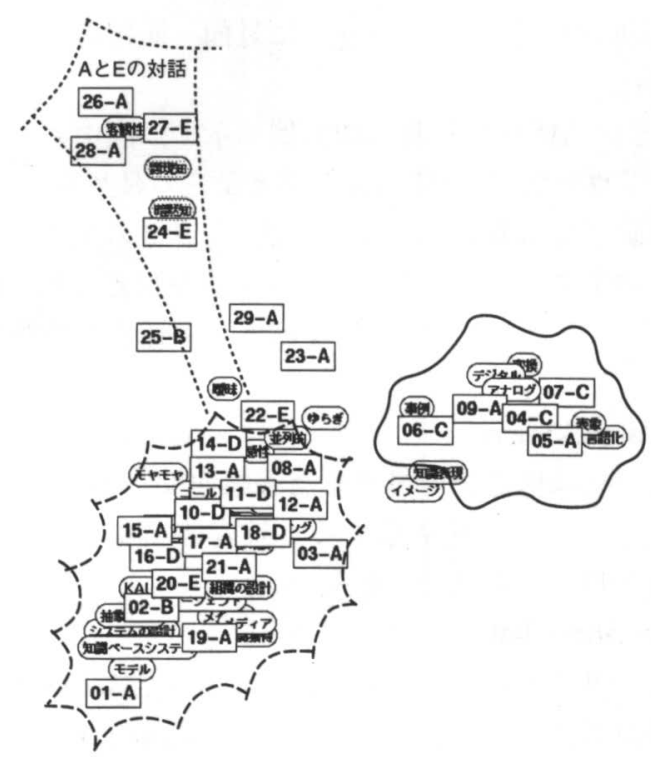

(3) New phase of the discussion

Fig. 3 Temporal Transition of Visualized Discussion Sturucture

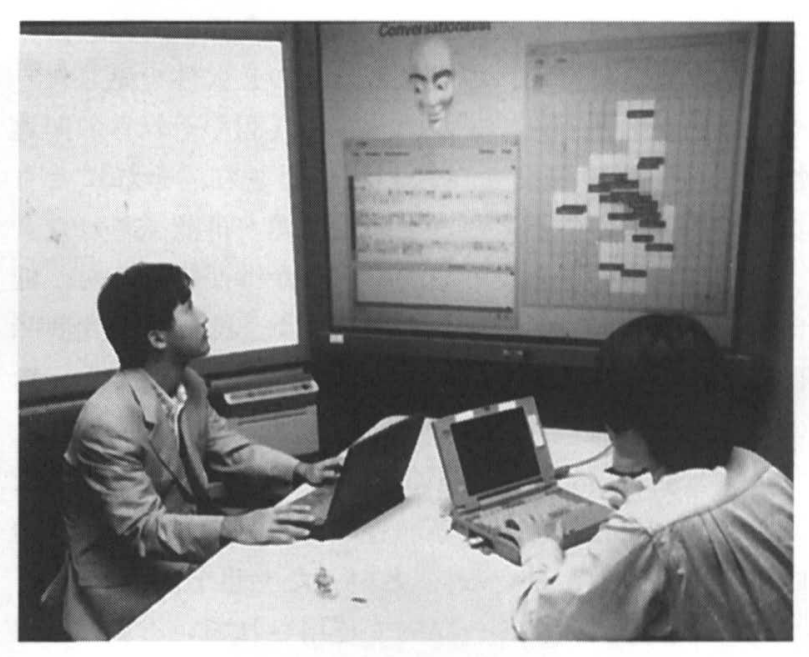

Fig. 4 AIDE Used in Face-to-Face Synchronous Mode

上で複製・修正することで共有情報を個人化すること ができる.

以下，これらのサブシステムについて簡単に説明する.

各ユーザはクライアントマシン上で Fig. 5 に示すよう なインタフェースを使用して議論に参加する. サーバは 発言の履歴情報とその構造を可視化した議論空間に関す る情報を管理している. 議論に参加するユーザの一人が 発言を入力すると, サーバはそのテキストから複数の キーワードを重要度付きで自動抽出し, その情報を元に して議論空間の可視化情報を更新する.

Discussion Viewer は基本的に CSS の機能を継承して おり, CSS と同様, 双対尺度法を利用して空間の自動 構成を行なう。議論空間上には, その時点までに投入さ れた発言を表すアイコンとそれらから自動抽出された キーワードを表すアイコンが自動配置される. ユーザは 議論空間を共有することで, 複数の話題（アイコンのク ラスタ）間の関連を認識しながら議論を進めることがで きる. 議論空間はキーワードの共有度という客観的で単 純な情報に基づいて発言間の関連性を可視化するため, 発言間の時間的な関係を捨象した関連性をユーザに気付 かせてくれる効果があり Fig. 5 中左にある発言履歴と相 補的に利用される。

次にConversationalist と呼ばれる仮想的な議論参加 者（自律的な情報検索サブシステム）について説明する. Conversationalist は, 議論の進行状況を観察しながら自 分の発言の夕イミングを計ったり, 議論履歴を解析して 発言内容を検討するといった能力を持っている. 発言内 容の元情報としては, あらかじめキーワードベクトルで インデキシングされたテキスト集合を含むテキストベー スを持つ. 検索戦略は複数用意しているが, 例えば, 検 索要求があったときの議論空間上に存在するキーワード 集合を検索キーとし, それとの正規化された内積が最も 高い値をとるキーワードベクトルを持つテキストを出力 する手法などがある. Conversationalist が出力したテキ ストとそれから抽出されたキーワードは議論空間に投入 


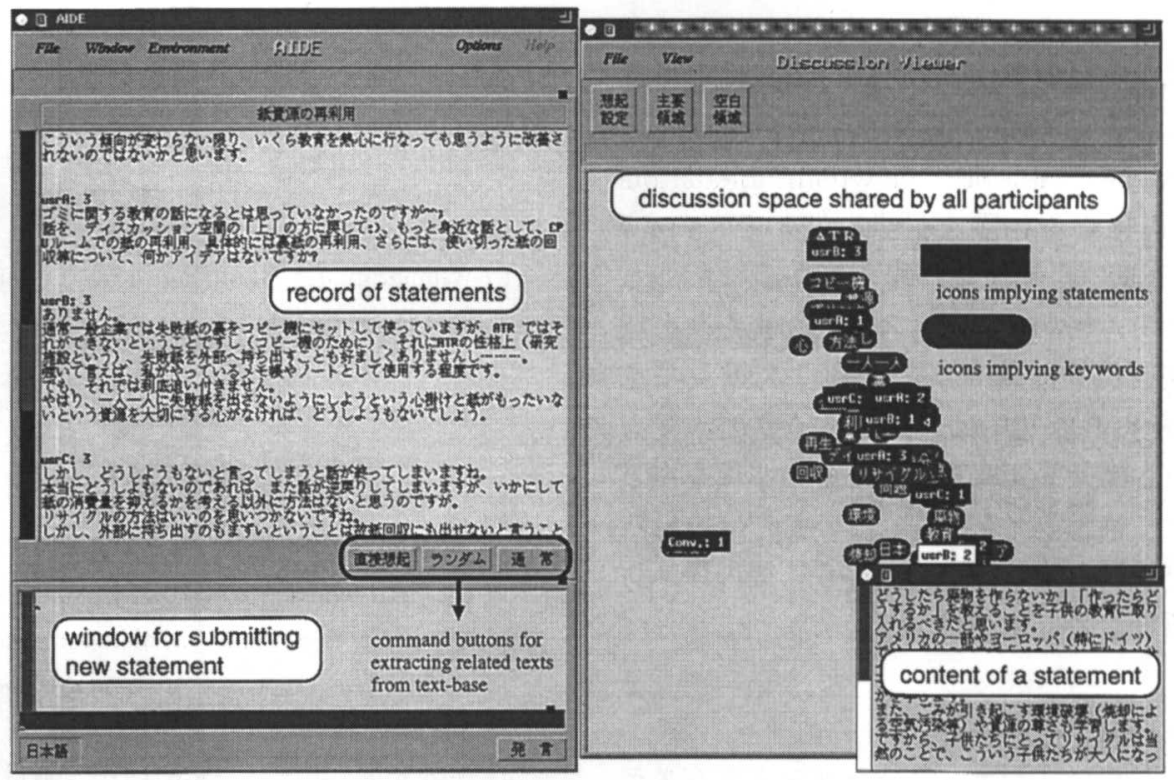

Fig. 5 Usage of AIDE

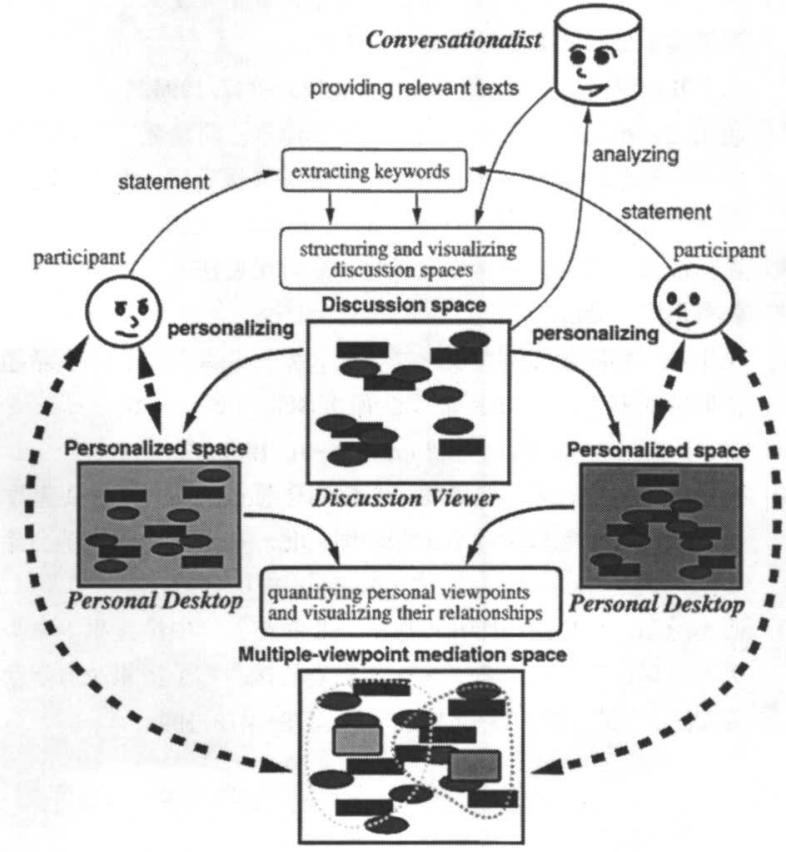

Fig. 6 Configuration of AIDE, and Viewpoint Sharing among Participants Using AIDE

され，通常の発言やキーワードと同様に空間配置の対象 となる.この情報は, ユーザらの思考の範囲の及ばなかっ た新たなアイデアの種を提供する可能性を持つと考える。

最後にPersonal Desktopについて説明する. Discussion Viewer が提示する議論空間は平均的な視点で議論 情報の構造を可視化するものであるから, 議論がある程 度進むと, 参加者各自の視点には必ずしも合わないもの になる可能性が高い. そこで各ユーザは議論への参加と 並行して，好きなときに議論空間をPersonal Desktop 上にコピーし，個人の思考モードに移ることができる.

Personal Desktop は, 処理する情報や可視化手段は Dis-

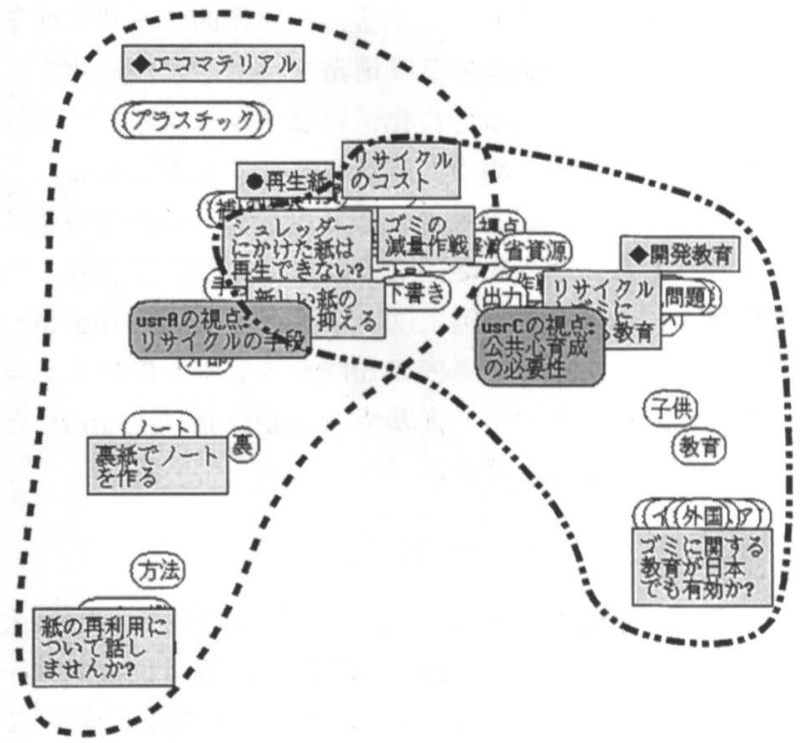

Fig. 7 Example of the Space Visualizaing Relationships Between Two Participants' Viewpoints

cussion Viewer と同様であるが，アイコンを自由に移 動することができる点, 発言やキーワードの削除や修正 ができる点, 他の参加者には未公開の個人的メモ等を処 理対象として加えることができる点で異なる．これらの 機能を利用することで，ユーザは共有の議論空間を個人 化することができ, Personal Desktop はユーザの視点 を反映した新しい個人化空間 (Fig. 6 の Personalized space）を可視化する.

したがって, 別のユーザの個人化空間内では, 同一の 発言対でもその相対的な位置関係がまったく異なること があり得る.そのような可視化情報を参加者間で共有し 合うことで, 議論内容に対する個人の視点の相違を共有 したり，更には新たな発想を期待することができると考 
える。

AIDEでは更に，各自の Personal Desktop 上で可視 化された個人的視点を定量化し，それらの関係を新たに 視点共有空間 (Fig. 6 の Multiple - viewpoint mediation space）として可視化する手段を提供している. Fig. 7 は，「オフィスでの紙の再利用」に関する議論に参加し た 2 人のユーザの個人化空間をすり合わせた視点共有空 間の例である（視点共有空間生成の詳細は文献 10）を 参照されたい)。視点共有空間は，複数ユーザ間の視点 の間の共有している部分と共有しない部分の関係を視覚 的に表現するので, 議論空間を共有しているだけでは気 付きづらいような，個人的な見解の相違や言葉の使い方 の個人差などを顕現化する効果がある.

\section{5.おわりに}

筆者らが開発してきたコミュニケーション支援システ ムCSS と議論支援システム AIDEを例に挙げ，テキス トオブジェクトを空間配置することによる議論の可視化 手法を紹介した，紹介した手法は，比較的ユーザに作業 負担をかけずに，議論の意味構造を自動的に可視化する ものであり, 得られる可視化情報はグループ内での相互 理解や情報伝達のための共有情報として有效である.

こういったコンピュータ上で表現される可視化情報は， ユーザである人間の組織内での共有情報として有効なだ けでなく，コーザと（例えば AIDEの Conversationalist のような) コンピュータ内の知的システムとのコミュニ ケーションを促進する共通基盤（Common ground）と しても有効であると考える。

\section{謝 辞}

本稿で紹介したCSSは, 東京大学において小川童太 氏, 堀浩一氏, 大須賀節雄氏との共同研究によって開発 された. AIDEは, ATR 知能映像通信研究所において 西本一志氏, 間瀬健二氏との共同研究によって開発され
た。これらで共通して利用された双対尺度法による可視 化部分の実装は杉本雅則氏による，以上の諸氏に深謝す る.

\section{参考文献}

1) Winograd, T.: A language 1 action perspective on the design of cooperative work. Human Computer Interaction, Vol. 3, No. 1 , pp. 3 30, 1988.

2) Conklin, J. and Begeman, M. L.: gIBIS: A hypertext tool for exploratory policy discussion. In Proc. CSCW'88, pp. 140 $\sim 152$. ACM, 1988.

3）角康之：情報可視化システムにおける適応的インタラクショ ン. 人工知能学会誌, Vol. 14, No. 1, 1999.

4) Hori, K. : A system for aiding creative concept formation. IEEE Trans. Systems, Man, and Cybernetics, Vol.24, No.6, pp. 882 294,1994 .

5) 杉本雅則, 堀浩一, 大須賀節雄：設計問題への発想支援シス テムの応用と発想過程のモデル化の試み.人工知能学会誌, Vol. 8, No. 5, pp. 575 582, 1993.

6）角康之, 堀浩一, 大須賀節雄：テキストオブジェクトを空間 配置することによる思考支援システム。 人工知能学会誌, Vol. 9, No.1,pp.139 147, 1994.

7) 角康之, 小川童太, 堀浩一, 大須賀節雄, 間瀬健二: 思考空 間の可視化によるコミュニケーション支援手法. 電子情報通 信学会論文誌, Vol. J 79-A, No. 2, pp. 251 260, 1996.

8 ）西里静彦：質的デー夕の数量化一双对尺度法とその応用一. 朝倉出版, 1982.

9）角康之, 間瀬健二：グループディスカッションにおける話題 空間の可視化. 情報処理学会研究報告（ヒューマンインタ フェース), Vol. HI $62-12$, pp. 83〜90, 1995.

10）角康之, 西本一志, 間瀨健二：協同発想と情報共有を促進す る対話支援環境における情報の個人化. 電子情報通信学会論 文誌, Vol. J 80-D-I, No.7, pp. 542〜550, 1997.

11）西本一志, 角康之, 門林理惠子, 間瀨健二, 中津良平: マル チエージェントによるグループ思考支援. 電子情報通信学会 論文誌，Vol. J 81-D-I. No. 5, pp. 478〜478, 1998. 


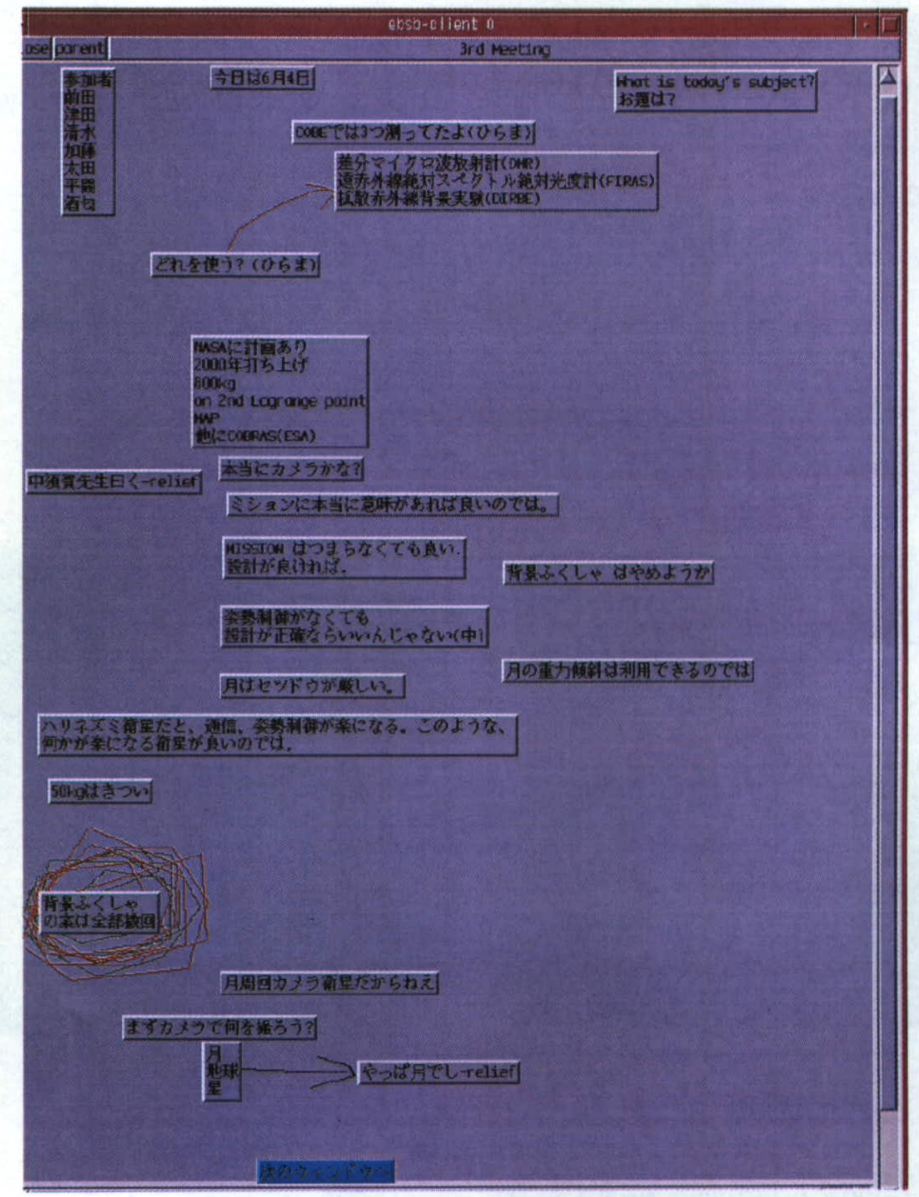

口絵 7 思考の一部を可視化するコンピュータシステムの出力例

（口絵 7 東京大学 堀 浩一) (本文 2 頁参照)

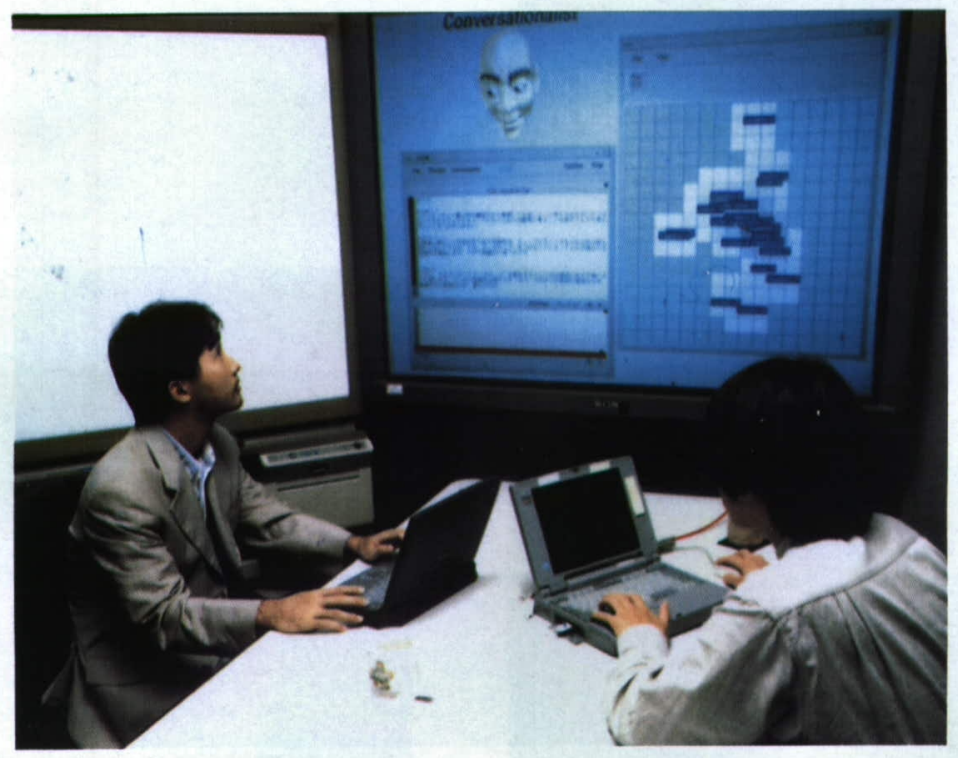

口絵 8 議論支援システム AIDE の使用概観 